\title{
The Art of Entrepreneurship, from Toni Sikes of CODAworx
}

Jon Eckhardt (University of Wisconsin-Madison)

KEYWORDS: Entrepreneurship, Leadership, financing, Women.

In her years as an entrepreneur, Toni Sikes has focused on helping artists find people who will pay for their work. Her company, CODAworx, serves as an online community for painters, sculptors, fabricators, architects, designers, developers and many others. In this interview, Sikes, who is both artists' advocate and venture capitalist, talks about the importance of knowing your customer, the art of luring top talent from established companies to the uncertain world of a startup, and how to make great things happen without cash.

\section{Read More:}

Advice, Best Practices and Inspiration for Women Entrepreneurs(https://eiexchange.com/women)

Additional search terms: women, feminism, female founders, women business owners, glass ceiling, opportunity, creative arts, artists 